\title{
Intimacy
}

\section{Ross GIBSON}

For three months in 2008, I staged a project as part of the Biennale of Sydney. The gist of it was this: I was available for conversations with anyone who wanted to pause and spend some time in a small alcove at the Art Gallery of New South Wales. I tallied five conversations per day, up to fifty minutes per conversation, across eighty consecutive days. ${ }^{1}$

The project was art, but it was research too. In the hundreds of unpredictable exchanges that ensued, participants initiated remarkable runs of thought, compassion and imagination. Time and again strangers shared intimate insights that drew us in close and turned the world around. Daily, I was struck by the importance of creating a space that is not only physical but also mental and emotional, a space where one can define and make claims for oneself in order to offer oneself more boldly to the world of everyday experience. I sensed how useful it is to mark your boundaries, to mark them but not entrench them. Day by day, I grew to understand how you need a solid subjective standpoint (or node) in order to move productively out to the larger world (or network) of others. The more solid your grounding, the more nimble you can be with the possibilities when encountering someone else. The more robust the node, the more resilient the entire network.

I noticed too how this mental and emotional standpoint is most stimulating when it is not entirely comfortable, when it has in it a modicum of intrigue and irresolution stimulating the participants to venture out past their habits and 
presumptions. I learned that an imaginative encounter needs to be convivial but not easy or predictable. The right amount of friction makes the right amount of warmth. A challenge makes a reward. And a limit allows growth that lets one's self push over to alteration. In my conversation alcove, I began to understand how the assertion of one's place can actually bring the world to you and through you. The boundary that you make can be with and for the larger world, not against it.

Over the course of the Biennale project, I became familiar with a wonderful artefact: an image by Yakaduna, a rural man, an Aboriginal man whose colonial name is recorded as Tommy McRae (born c. 1835, died 1903). He lived on the plains of the upper Murray River. His picture, called 'Sketch of Squatters. Drawn by Tommy an upper Murray Aboriginal. 1864', was part of the 'decor' in the nook where my project took place. The sketch is a tiny ink drawing, maybe fourteen by ten centimetres, showing the barest graphical rendition of six silhouetted European figures gathered in a chattery gaggle, gesticulating and standing with legs firmly planted on the colonised ground.

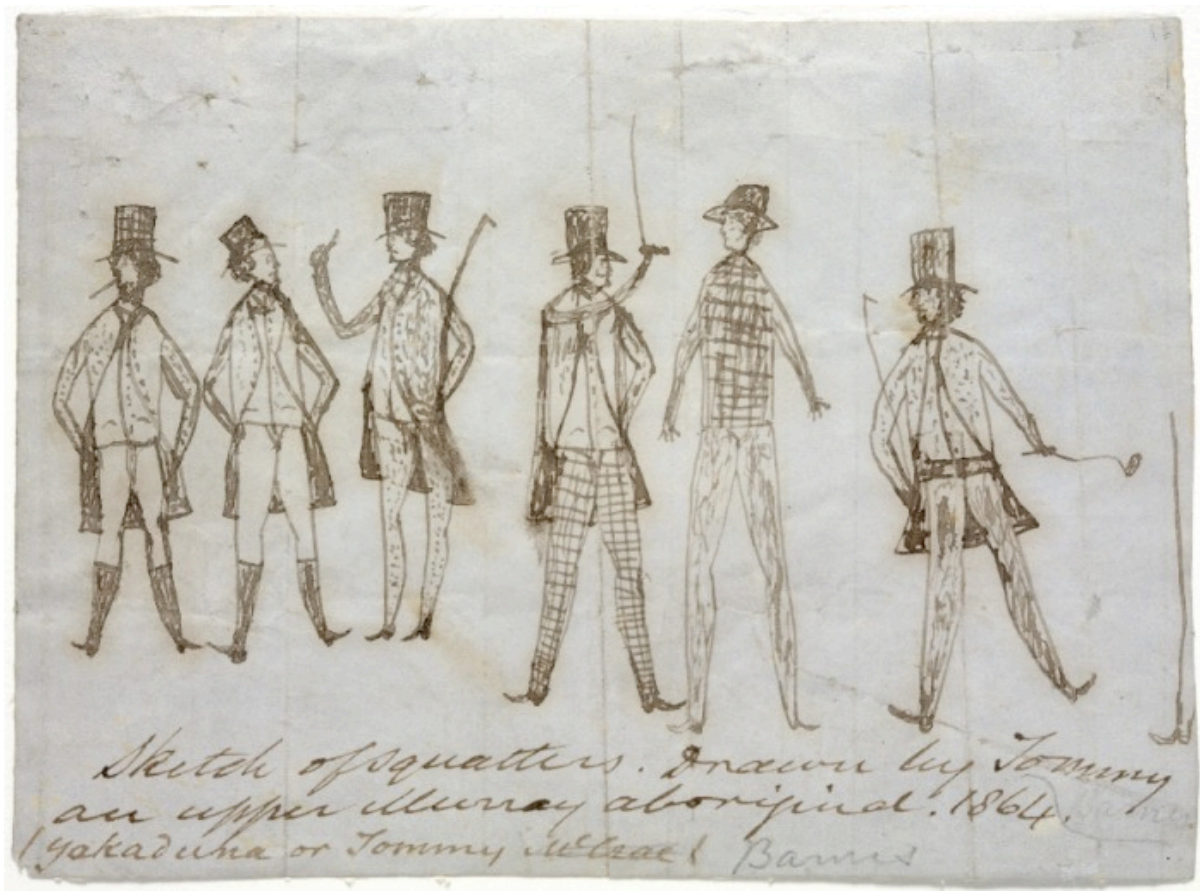

Sketch of Squatters. Drawn by Tommy an upper Murray Aboriginal. 1864 (Mitchell Library, State Library of New South Wales) 
What's striking is how Yakaduna has conveyed the paradoxically competitive camaraderie among the squatters. Adapting European aesthetics and materials to his own sensibility, he shows not only how flushed with bravado the squatters are, now that they have entered his country from elsewhere, but also how poignantly they need each other in their newness to the scene; he shows how much they want to get the jump on each other but also how they dare not isolate themselves in this place that they cannot claim to know well even as they have claimed it administratively. It's a scene painted by someone who can still remember belonging. To my eyes, the sketch is a beautifully nuanced study of alienation, stalled belonging, the exact opposite of intimacy. For all their bluster and energy, the squatters seem at odds with each other and their environs. They appear unsettled, alienated from the ground they occupy. Untethered. And little bit mad with the their jumpy eagerness to gesticulate and make claims.

So the picture makes a point. It is polemical. Imaginative too. Gazing on its meagre lines, you can't help but conjure the scene in which this rural Indigenous man is adapting the new, imported technologies of paper and ink to his own purposes, working out how to convey some of the ideas and emotions that were bursting over his cognition and infiltrating his inherited sense of place now that the squatters' powerful new world had come to his ancestral country. The picture is a poetic conundrum in this regard, holding several contradictory propositions and difficult moods in a highly suggestive array. It stands as a precursor to the great flourishing of imagination that has come, in recent decades, from hundreds of rural Indigenous painters.

Every day during the Biennale, I studied Yakaduna's sketch. It never stopped giving me something. It never resolved itself. Often I had extensive conversations about it, speaking to strangers with whom I was able to develop a quick fellow feeling as we wondered about how the sketch was produced and for whom it was produced. One of us usually concluded that the picture was made as much for us here in the future even as it was also made on request back then by some settler with a meagre payment or a curt demand.

In other words, the picture was and remains part of an economy that cannot be separated from the grim history of colonialism, a history of the European metropolis arriving to mark out the divisions between the rural and the civic. 
Here is a peculiarity of rural cultural studies in a location such as Australia: just as contemporary rural people seem repeatedly obliged to define and assert themselves against a potentially overwhelming urban power, so this push and pull has happened before. Indigenous people felt a similar takeover, more directly violent in the enactment. In Australia, colonialism made the rural parts of the country just as it made an administrative vantage for itself in making the cities. All the while, close feelings were corroded and negated-feelings of belonging, of custodial rights and responsibilities, of deeply felt and strenuously won knowledge. So, rural cultural studies are also colonial studies, because the rural was made by the colonial. And colonial studies are ideological, economic, military and geographical; but they are also intimate, detailed and full of sentiments like rage, love, pride and grief. This is not to propose any simple parallel between the Rural and the Indigenous. But they are enmeshed.

Clearly, nothing is simple across this aftermath country, despite how many people wish or insist it were so. History, presumption, power and allegiance entangle rural existence with arcadian or pastoral stereotypes and with myths and histories of indigeneity, all in messy contest with far-reaching bureaucracies administered through metropolitan agencies. How insidiously do the definitions of 'the rural', 'the Indigenous' and 'the urban' trouble each other but also depend on each other! And how needfully do they borrow from each other even as they assert differences. As an exercise, try making a claim about yourself, using all three categories. For example: 'I am rural but, because I am not Indigenous, I am complicit with urban history, influences and values'. Or: ' I am Indigenous and urban and have no allegiance to the rural.' Or: 'I am urban but I yearn for the rural life and sometimes I sense inklings that feel somehow indigenous.' Or: 'I am only one of these things and the other two are a curse to me.' And so on. The point of the exercise is to sense how difficult it is to come up with a settled, easeful sentence combining yourself and the three terms. The point is to feel how charged the terms are, how tense with history and sore with memory they are, how much trouble they make together, and how interdependent and inseparable they are.

What is at stake when you assert your belonging in a rural zone? Or when you proclaim your valid knowledge of it? Or your difference from it? 
Throughout the months of the Biennale project, scrutinising Yakaduna's witty sketch of those uppity rural men who had recently arrived via some metropolis, I marvelled at how a painting can conjure a world that is so counterposed with polemic and possibility, a world without settlement, restlessly ambiguous, generation after generation. How vividly the painting shows that the ground we are on-be it rural, be it urban, be it national-is still thoroughly colonial and up for grabs.

'Rural'. 'Urban'. 'Colonial'. 'National'. These are the first keywords that I would nominate for this particular issue of Cultural Studies Review. But they are blunt instruments. They are too charged and all-encompassing to be of precise use. They need sub-categories. So here, gathered in one list, are the more specific keywords that all the authors have nominated:

belonging, emotion, emotional ecology, listening, rural, sound-local, identity, ethics, indigenisation, belonging, lichtung (clearing)—procedural justice, city-bush divide, political histories-walking, surfing, coast, weather, research methodology, writing-snow conditions, climate change, regional Australia, Tasmania, cultural values, emotional responses-research relations, power, interview methods, public housing, rural-quantification, dread, desire, connectedness, commerce, love. [Note: the last six keywords have been added by me, extrapolating from the contributions by those writers who chose not to nominate any categories.]

When I assay this list of keywords and then go back to re-read the full essays, I find that the theme threading through just about every text is: intimacy. Questions of intimacy impel the writing. How to catch the special sounds and smells, the closely felt rhythms and textures, the particular qualities and rituals that define a rural place? How to bear witness to the convictions that locals carry within their rural domains? How to tally the force and value of someone's resolve to make a go of it in the rural zones, away from the administrative engines and gears in the cities? The answers to such questions have something to do with the rural person's avid sense of connection; something to do with how people care about a place and, by extension, how much they are roused to care for it. And this is all connected to how strongly people are compelled to assert (or perhaps to traduce sometimes) the 
particular qualities of their places, how strongly they maintain the boundaries that differentiate their special home-places from other regions.

The rhythm of ritual is crucial to this sense of assertive involvement with a particular place. From repetitions that are freely given, not just from drudgery, a person can develop a sense of being stitched in to a place, stitched in the sense not only of being attached to the place but also of helping to hold it together, trussing it with meanings and patterned continuity. Out of such freely given repetitions, something technical and closely felt can emerge: enchantment. Which is literally an experience whereby one can chant oneself and one's place into each other, an experience that is creative, reiterative and constantly careful. It's a process concerned to maintain distinctiveness, to hold firm not only against inherent decay but also against incursive duress.

To find the courage (which comes from 'le coeur'-the heart) to work and hold firm like this, you probably need to feel the value of a place, to care enough about it and to feel so much closeness that you take care of the poignant details, again and again, ritually and assertively. It is personal, this moment when you evaluate the worth of so much effort. It is an intimate moment if you make a commitment. Heartfelt. And the sequence that follows from such moments-the sequence of care-is loving somehow.

Amidst all the politics and scepticism that are rightly parlayed in these essays, this is most telling word that turns up now and then in the texts-love. Finally, no matter how shy we are to deploy this term in the social sciences, I reckon this phenomenon-love-looks like the most compelling and all-encompassing keyword to brand the surprisingly intimate domain that has been surveyed in these essays, the domain of rural cultural studies.

'What is to be done?' It used to be politics that roused this big question. But wherever the rural resides, it seems love can rouse the question too. Which is not to say that the question and rural cultural studies have ceased to be political.

Ross Gibson makes books, films and art installations. Recent works include the book The Summer Exercises (2010), the video installation 'Street X-Rays' and the interactive audiovisual environment BYSTANDER (a collaboration with Kate 
Richards). He is the Professor of New Media and Digital Culture at the University of Technology, Sydney. <Ross.Gibson@uts.edu.au>

-NOTES

${ }^{1}$ See <http://conversationsii.bos2008.com>. 